\title{
THE SERUM CALCIUM IN POLYCYTHEMIA VERA
}

By ETHEL M. BENEDICT AND KENNETH B. TURNER

(From the Department of Medicine, College of Physicians and Surgeons of Columbia University and the Presbyterian Hospital, New York)

(Received for publication May 28, 1930)

In a study of fourteen cases of polycythemia vera, Brown and Roth (1) found the serum calcium to be over $11.0 \mathrm{mgm}$. per hundred cubic centimeters in every case. The actual range of serum calcium values was 11.1 to $18.1 \mathrm{mgm}$. per hundred cubic centimeters. The average value for the group was $14.3 \mathrm{mgm}$. These authors noted a reduction in

TABLE 1

Data on patients

\begin{tabular}{|c|c|c|c|c|c|c|c|}
\hline $\begin{array}{c}\text { Case } \\
\text { number }\end{array}$ & Sex & Age & $\underset{\text { (Sahli) }}{\text { Hemoglobin }}$ & $\begin{array}{l}\text { Red blood } \\
\text { cells }\end{array}$ & $\begin{array}{c}\text { White blood } \\
\text { cells }\end{array}$ & $\begin{array}{c}\text { Serum } \\
\text { calcium }\end{array}$ & $\begin{array}{c}\text { Spleen } \\
\text { palpable }\end{array}$ \\
\hline & & & per cent & millions & & $\begin{array}{l}\text { mgm. per } \\
100 \text { cc. }\end{array}$ & \\
\hline 1 & M. & 54 & 107 & 7.5 & 20,300 & 10.0 & + \\
\hline 2 & M. & 53 & 132 & 9.7 & 13,000 & 10.7 & + \\
\hline 3 & F. & 63 & 125 & 7.0 & 16,200 & 7.9 & + \\
\hline 4 & M. & 44 & 128 & 6.6 & 15,200 & 11.0 & 0 \\
\hline 5 & F. & 60 & 119 & 7.8 & 14,700 & 10.8 & + \\
\hline 6 & M. & 47 & 160 & 10.3 & 7,800 & 12.9 & + \\
\hline 7 & M. & 47 & 102 & 6.9 & 11,600 & 10.7 & + \\
\hline 8 & M. & 46 & 125 & 9.0 & 9,500 & 9.9 & + \\
\hline 9 & M. & 57 & 128 & 8.9 & 15,200 & 11.3 & + \\
\hline
\end{tabular}

serum calcium accompanying a fall in red blood cell count following treatment with phenylhydrazine.

We were stimulated by this report to make some additional studies of the calcium metabolism in polycythemia, but the work was halted in its incipiency by our inability to confirm the findings of Brown and Roth.

Serum calcium determinations were made in nine cases of typical polycythemia vera using Clark and Collip's modification of the method of Kramer and Tisdall (2). The patients received no special diet, and 
in only one (case 6) was phenylhydrazine administered before the first calcium determination was made. The results are shown in table 1.

From this tabulation it can be seen that in only two of the nine cases was the serum calcium in excess of $11.0 \mathrm{mgm}$. (12.9 and $11.3 \mathrm{mgm}$.) while in one case it was considerably less than $9.0 \mathrm{mgm}$. (7.9 mgm.). The remaining six cases all showed perfectly normal serum calcium values. The average for the group was $10.6 \mathrm{mgm}$.

From these findings we conclude that there is no significant variation in the serum calcium in polycythemia vera.

\section{BIBLIOGRAPHY}

1. Brown, G. E., and Roth, G. M., J. Clin. Invest., 1928, vi, 159. The Reduction of Hypercalcemia in Cases of Polycythemia Vera by Phenylhydrazine.

2. Clark, E. P., and Collip, J. B., J. Biol. Chem., 1925, 1xiii, 461. A Study of the Tisdall Method for the Determination of Blood Serum Calcium with a Suggested Modification. 